\title{
Is There a Non-linear Relationship between Net Trade Cycle and Corporate Performance in Turkey?
}

\author{
Mehmet Erkan Soykan ${ }^{1}$, Recep Ulucak ${ }^{2}$ \\ ${ }^{1}$ Social Sciences Vocational College, Erciyes University, Kayseri, Turkey \\ ${ }^{2}$ Faculty of Economics and Administrative Sciences, Erciyes University, Kayseri, Turkey \\ Correspondence: Mehmet Erkan Soykan, Social Sciences Vocational College, Erciyes University, Kayseri, Turkey
}

Received: March 16, 2016

Accepted: March 21, 2016

Online Published: April 11, 2016

doi:10.5539/ibr.v9n6p95

URL: http://dx.doi.org/10.5539/ibr.v9n6p95

\begin{abstract}
The aim of this study is to examine the relationship between working capital management and corporate performance for non-financial firms quoted in Borsa İstanbul for the period 2009-2014. The working capital investment decisions of the firms are utmost important since firms can continue their operations without discontinuance, raise their value and reduce risks as long as working capital level is attentively administered. Our research contributes to the working capital literature by investigating the non-linear relation between net trade cycle (NTC) and firm performance, utilising contemporary data and using system Panel GMM method. Our results indicate that there is a non-linear relationship between NTC and corporate performance. This means that there is an optimal NTC value where firm value is maximised. At this optimal working capital level, costs and advantages are poised. This implies that corporate executives should carefully manage their working capital investment and strive to be close to the optimal level as much as possible.
\end{abstract}

Keywords: Borsa İstanbul, firm performance, net trade cycle, working capital management

\section{Introduction}

Corporate finance has shown up by the function of providing the funds which the firm needs and since the second half of 20th Century it has expanded to a change which includes the functions of distributing funds to assets in a proper manner and ensuring the effectiveness in the management of assets. In line with the change, besides long term investments in financial decisions, also short term investment decisions have started to be emphasized in terms of ensuring effectiveness. Thus, the location and importance of working capital management in the issues tackled by corporate finance have started to increase (Dursun \& Ayrıçay, 2012).

Firm fulfills three basic functions which are production-sales-collection. If these three basic functions are carried out at the same time, the management of working capital will not be important. If the firm has the opportunity to sell the products it produced immediately, stock management will disappear. In the same way, if the firm adopts the policy of performing sales as advance, it will not need receivable management. The mobility of working capital components is high and these components are related interiorly (Çakır \& Küçükkaplan, 2012).

Some firm-related factors which affect working capital necessity are firm type, activity subject, size, supply and sales conditions, the liquidity status of firm, stock valuation methods, capacity and usage level, production duration, cost of capital, the attitude of managers against risk and some external factors that influence working capital need are tax applications, investment incentive measures, changes in price level, technological variation and development level of financial institutions (Aktaş, 2016).

The investment on working capital has importance because firms can continue their activities without interruption, sustain their production effectively, minimise the risks which they can face and keep up their operations lucratively if they adjust their working capital carefully (Toraman \& Sönmez, 2015). Heavy conditions of competition which firms face in domestic and foreign markets and especially the economic crisis that show up typically further increase the importance of cash management and liquidity control. In the periods of recession, firms can continue their lives by reducing or delaying their long term investments, but if they do not give enough importance to working capital, they may be obliged to stop their activities completely (Yücel \& Kurt, 2002). An efficient working capital management can be claimed to be more important for the firms, which are active in emerging countries such as Turkey. Because one of the most emphasized hurdles fronted by emerging country firms appears to be liquidity (Karadagli, 2013). If working 
capital is financed with liabilities, firm can fall in financial difficulty as it needs to finance with short term bank credits when bank credits are tightened and interest rates rise especially in inflationary environment in which tight money policy is followed (Aktaş, 2016).

Working capital financing strategies comprise of combination of factors such as liquidity, risk and profitability. There is an inverse relationship between liquidity degree and profitability. As liquidity increases, firm's earnings which will be obtained from cash assets will decrease. When the liquidity teems, this causes the risk to diminish. The relation between risk and profitability is directly proportional. As the risk diminishes, also profitability decreases (Çakır \& Küçükkaplan, 2012).

Working capital is a crucial constituent of cash flow from functioning and cash flow from functioning is element of the assessment of free cash flows. For this reason, we can suppose that the well run administration of working capital is value relevant to any firm. Therefore, it is possible to mention that efficient administration of working capital is an important component of the comprehensive strategy of any firm to generate shareholder value (Almeida \& Eid, 2014).

As indicated above, successful administration of resources will result in higher firm value. But it is a question how to measure administration success, for example diminishing credit term can result in higher value but this can also result in decreased sales and market share. We believe that working capital management is ably designated by net trade cycle (NTC). NTC embraces all three very crucial features of working capital management. It is a sign of how long a firm continues if it ceases its activities or it shows the time interval between the acquisition of goods and collection of accounts receivable (Lazaridis \& Tryfonidis, 2006).

There are numerous clarifications for the motivations of the firms to possess positive working capital. Holding working capital may function for safety by supplying liquidity when firm falls into cash deficit. When the firm provides with more term on its sales, this reinforces long-term vendor-client connection, raises its sales as it can be perceived as an advantage by the buyers. Indeed in today's competitive economy, increasing term is a way of achieving differentiation. It also permits customers to assess good and service quality before making the payment. This serves to diminish the asymmetric information between the firm and purchaser. It also bolsters buyers to make purchases in the periods of little demand. Secondly, when the firm decreases its accounts payable, it can enjoy early payment deduction. Thirdly, by keeping high levels of stock, firms abstain from elevated manufacturing costs which occur from high undulation in manufacturing process. Also, this permits the firms to provide better service to their clients. By this way, firms can decrease procurement costs and price movements and they can obstruct pauses in the manufacturing process and loss of sales because of shortage of goods (Banos-Caballero, Garcia-Teruel, \& Martinez-Solano, 2014).

Nevertheless, several possible unfavourable impacts of investment in working capital also exist and these can cause a negative effect on the value of firm at particular working capital grades. Holding high working capital grade may cause to bind fund as working capital, for this reason high level of investment in working capital can avert the capability of firms to commence other value-augmenting projects. A high grade of working capital also specifies a requirement for extra fund, that the firm has to finance and it includes financing costs and alternative costs. Apart from this, when the firm possesses high grade of working capital, this may end up with high interest expenditure and consequently more credit risk. When the investment in working capital surges, the possibility that firm will encounter financial distress and insolvency increases. For these reasons, firms which have high level of working capital have motivation to diminish their grade of working capital and reduce the risk of financial distress and insolvency. Also holding more inventory increases costs such as security, storehouse rent and assurance expenditure (Banos-Caballero et al., 2014).

These positive and negative working capital impacts show that judgments about the working capital level include a trade-off. Therefore, it is anticipated that firms have an optimal working capital grade which counterpoises these expenses and advantages and maximizes their value. Particularly, it is anticipated that firm's performance will increase as working capital level surges until a specific working capital grade is arrived. On the contrary, we foresee that, past this optimal level, the association between performance and working capital will be negative (Banos-Caballero et al., 2014).

Our article contributes to the working capital management literature in the following manners. First of all, to our knowledge, this is the first study in Turkey which examines the non-linear association between NTC and corporate performance for the non-financial firms which are quoted in Borsa İstanbul. Aytürk and Yanık (2015) have examined the non-linear relation between cash conversion cycle and firm profitability rather than corporate performance and for the SMEs (Small and medium-sized enterprises) rather than the non-financial firms in Borsa İstanbul. For this reason, our dependent variable and data set are different from Aytürk and Yanık (2015). In our research, we mainly follow the methodology and model developed by Banos-Cabellero et al. (2014). Secondly, we utilise up-to-date data in our research, which is another contribution to the literature. Thirdly, we employ Arellano and Bover (1995) and Blundell and Bond (1998) system Panel GMM method in the analysis. 
The remaining of this paper is arranged as follows: In section two we provide literature review. Data set and model succeeds in section three. Section four involves method and application results. Ultimately, conclusion is made in section five.

\section{Literature Review}

In literature, there are many studies which examined the relationship between working capital management and firm performance, value or profitability both in Turkey and abroad. Below some recent studies in Turkey have been summarised. In these studies, different independent variables such as current ratio, liquidity ratio, net working capital ratio, number of days accounts receivable, number of days accounts payable, number of days inventory, operating cycle, cash conversion cycle etc. are utilised.

Akbulut (2011) analysed the association between working capital management and profitability for manufacturing firms listed in Borsa İstanbul in the period 2000-2008. In the analysis, cash conversion cycle is used for measuring working capital management. The findings show a negative association between working capital management and profitability. Also it is found from ANOVA analysis that cash conversion cycle differs in manufacturing sectors.

Çakır and Küçükkaplan (2012) researched the relation between working capital components (liquidity ratios, receivable turnover and inventory turnover) and firm profitability \& value. The findings indicate that there is negative association between current ratio, leverage ratio and firm profitability (ROA) and there is positive relation between quick ratio, inventory turnover, asset turnover and firm profitability (ROA). No significant relation between components of working capital and ROE or market value is found.

Dursun and Ayriçay (2012) investigated the connection between working capital and gross profit for 120 production and business firms which are registered in Borsa İstanbul in the time period 1996-2005. They utilised Least Squares Method (LSM) in the research. A negative relationship between working capital components and gross profit is found.

Vural, Sökmen and Çetenak (2012) examined the association between working capital management constituents and performance of firms by utilising dynamic panel data analysis for the interval 2002-2009. Their findings show that firms can increase profitability measured by gross operating profit by cutting collection period of accounts receivable and cash conversion cycle and firms can increase firm value (TOBINQ) by expanding cash conversion cycle.

Çakır (2013) analyzed 52 manufacturing firms which are traded in Borsa İstanbul for the period of 2000-2010. According to the research results, it is concluded that higher cash conversion cycle is related with higher profitability in the manufacturing sector which was an unexpected result by the author.

Karadagli (2013) investigated the effect of cash conversion cycle and its single parts on firm profitability which are operating income and stock market return for the data between 2001 and 2010. Also potential impacts of group affiliation on the effect of CCC and its parts on firm profitability are examined. According to the results of this study, curtailing of CCC and its parts, increase both firm profitability measures, which are examined.

Demireli, Baş̧̧ı and Karaca (2014) examined the relationship between working capital and performance indicators, which are ROA, ROE, market to book value ratio and TOBINQ in the period 1998-2010. The sectors investigated are real estate investment trusts, mining, technology, commerce and manufacturing. Sales variable is found to be significant in explaining market to book value ratio.

Konuk and Zeren (2014) investigated whether firms in Food and Beverage Index in Borsa İstanbul have optimal cash conversion cycle by utilising quarterly data between 2008 and 2013. They concluded that these firms do not possess optimal working capital cycle, their cash conversion cycle varies from average in long-run and owns a volatile structure.

Toraman and Sönmez (2015) analyzed 11 retail trade firms which are registered in Borsa İstanbul for the period between 2009-2013 and results show that there is no relation between working capital variables and gross profit.

Aytürk and Yanık (2015) examined the relationship between working capital management and profitability for Turkish SMEs for the 2009-2013 period. The firms chosen are not specifically gathered from Borsa İstanbul but rather from Orbis database. Their panel data analysis by utilizing system-GMM estimators indicate that a negative relation exists between cash conversion cycle and profitability.

Finally, below some examples of studies which are made abroad and are in this field are given:

Deloof (2003) analysed the affect of working capital on profitability by using Belgian firms for the period between 1992 and 1995. According to the research results, a significant negative association between gross operating income and the number of days accounts receivable, inventories and accounts payable is detected.

Lazaridis and Tryfonidis (2006) examined the association of corporate profitability and working capital management. They utilised a sample of 131 firms which are listed in the Athens Stock Exchange (ASE) for the data between 2001 and 
2004. Their findings indicate a negative relation between cash conversion cycle and profitability which was measured as gross operating profit.

Nazir and Afza (2009) analysed the relation between working capital administration approaches and profitability by focusing on Pakistani firms for time period 1998-2005. They used ROA and Tobin's q as dependent variables and concluded that firm executives can generate value if they employ a conservative policy in working capital investment and working capital financing approaches.

Banos-Cabellero et al. (2014) investigated the relationship between working capital management and corporate performance for the UK firms, which are non-financial. According to their analysis results, there is an inverted U-Shaped relationship between investment in working capital and firm performance. This means that there is an optimal level of investment in working capital which stabilizes costs and benefits and maximizes a firm's value.

\section{Data Set and Model}

In this study, we analyse 123 non-financial firms which are quoted in Borsa İstanbul for the period between 2009-2014. The firms which are analysed are listed in Appendix A. The variables which are used in the analysis are summarised in Table 1.

Table 1. Data Set and Descriptions

\begin{tabular}{ll}
\hline Variable & Explanation \\
\hline Q & (Market Value of Equity+ Book Value of Debt)/ (Book Value of Assets) \\
\hline NTC & (Accounts Receivable/Sales)*365+(Inventories/Sales)*365-(Accounts Payable/Sales)*365 \\
\hline SIZE & Natural Logarithm of Sales \\
\hline LEV & The Ratio Of Total Debt to Total Assets \\
\hline GROWTH & Sales Growth / Total Assets Growth \\
\hline ROA & Earnings Before Interest and Taxes/ Total Assets \\
\hline
\end{tabular}

Note $. \mathrm{Q}=$ Corporate performance, $\mathrm{NTC}=$ Net Trade Cycle, SIZE $=$ Size, LEV = Leverage, GROWTH= Growth Opportunities, ROA= Return on Assets

Our data is yearly and includes the non-financial firms which are listed in Borsa İstanbul. There are some advantages of utilising data from stock exchange. For example, the listed firms' financial statements are believed to be more reliable than the non-listed firms in Turkey. Because listed firms have more motivation to report profits if they exist with the wish to make their shares more appealing and their financial statements are subject to tougher audit. However, non listed firms mostly have less motivation to report true operational results and financial status. These non listed firms commonly conceal profits if they exist with the purpose of paying less corporate tax. For these reasons, we believe that these listed non-financial firms are better candidates for our research in which the relationship between working capital and firm value is explored (Lazaridis \& Tryfonidis, 2006).

Two different models are used in the empirical analysis. In Model 2, as a difference from Model 1, the square of NTC variable is utilised and it is determined whether there is a non-linear relation between NTC and Q. Model 1 and Model 2 are constructed as below:

$$
\begin{aligned}
& Q_{i, t}=a_{0}+a_{1} Q_{i, t-1}+a_{2} N T C_{i, t}+a_{3} S I Z E_{i, t}+a_{4} L E V_{i, t}+a_{5} G_{R O W T H_{i, t}}+a_{6} R O A_{i, t}+e_{i t} \\
Q_{i, t}= & a_{0}+a_{1} Q_{i, t-1}+a_{2} N T C_{i, t}+a_{3} N T C_{i, t}^{2}+a_{4} S I Z E_{i, t}+a_{5} L E V_{i, t}+a_{6} G_{R O W T H_{i, t}}+a_{7} R O A_{i, t}+e_{i t}
\end{aligned}
$$

In the models, $\mathrm{i}$ represents firms and $\mathrm{t}$ represents time dimension. From the fact that economic situation in $\mathrm{t}$ period is to a large extent under the influence of past experience and behaviour forms and dynamic structure is obtained by using lagged value of dependent variable as explanatory variable (Baltagi, 2014), a dynamic structure is formed in the model by including one period lagged value of dependent variable (t-1) in the analysis.

Our hypothesis is that the coefficient of $\operatorname{NTC}^{2}\left(a_{3}\right)$ in the Model 2 is negative. Because we expect that firms examined possess an optimal working capital grade which equalizes the benefits and costs of keeping working capital and maximizes their performance. We anticipate that NTC and firm performance have a positive association at low grades of working capital and have a negative relationship at higher grades.

\section{Method and Application Results}

In order to examine the firms, which are included in the analysis, as a whole and to consider the variability in the firms in this integrity and the unobservable heterogeneity in the model, to reduce the estimation bias, to diminish the multicollinearity problem and to prevent the degrees of freedom deterioration, we preferred panel data method for the analysis to benefit the advantages mentioned.

In the analysis, it is intended to form a dynamic model by using lagged value of dependent variable as explanatory variable. But in dynamic models fixed effects estimator is not consistent since it is required to take the first difference 
(Han \& Phillips, 2010). In these situations Anderson and Hsiao (1981) instrumental variable estimator or Arellano and Bond (1991), Arellano and Bover (1995), Blundell and Bond (1998) generalized method of moments (GMM) is widely utilised. GMM approach is also fundamentally an instrumental variable method and it is more suitable for the analysis in which cross-section dimension is greater than time dimension (as it is case for our study) (Cameron \& Trivedi, 2009). Likewise in this method it is taken into account the fact that error terms may have heteroscedasticity when two-stage calculation is chosen (Khadraoui, 2012). Hence Arellano and Bover (1995) and Blundell and Bond (1998) system Panel GMM method is used to obtain reliable results. Application results are presented in Table 2.

Table 2. Panel GMM Estimation Results

\begin{tabular}{|c|c|c|}
\hline \multirow[b]{2}{*}{ EXPLANATORY VARIABLES } & \multicolumn{2}{|c|}{ DEPENDENT VARIABLES } \\
\hline & Model 1 & Model 2 \\
\hline$Q_{t-1}$ & $0.43651 * * *$ & $0.42519 * * *$ \\
\hline$N T C$ & 0.00034 & $0.00288 *$ \\
\hline$N T C^{2}$ & - & $-0.000008 *$ \\
\hline$S I Z E$ & $-0.2396 *$ & $-0.39410 * * *$ \\
\hline $\boldsymbol{L E V}$ & $-1.4178 * * *$ & $-1.09672 * * *$ \\
\hline GROWTH & $0.00178 * *$ & $0.00210 * * *$ \\
\hline $\boldsymbol{R O A}$ & $1.49310 * *$ & $1.89955 * * *$ \\
\hline CONSTANT & $6.05178 * *$ & $8.79255^{* * *}$ \\
\hline Wald $\left.\mathbf{I}(\chi]^{2}\right)$ & $\begin{array}{l}451.50 \\
{[0.0000]}\end{array}$ & $\begin{array}{l}451.38 \\
{[0.0000]}\end{array}$ \\
\hline Sargan $\mathbf{l}\left(\chi^{]^{2}}\right)$ & $\begin{array}{l}112.382 \\
{[0.3418]}\end{array}$ & $\begin{array}{l}112.689 \\
{[0.3850]}\end{array}$ \\
\hline $\operatorname{AR}(1)$ & $\begin{array}{l}-3.3908 \\
{[0.0012]}\end{array}$ & $\begin{array}{l}-1.70282 \\
{[0.1070]}\end{array}$ \\
\hline $\operatorname{AR}(2)$ & $\begin{array}{l}-1.7180 \\
{[0.1040]}\end{array}$ & $\begin{array}{l}-1.11395 \\
{[0.2414]}\end{array}$ \\
\hline
\end{tabular}

Note. $* * *, * *$ denotes $10 \%, 5 \%$ ve $1 \%$ significance level respectively and brackets contain probability values

According to results of the Wald test, which tests whether the model as a whole is significant or not, Sargan test, that tests the validity of instrumental variables and $\operatorname{AR}(1)$ and $\operatorname{AR}(2)$ test, which test the autocorrelation in the model, the outcomes are reliable. In autocorrelation tests, especially the results of $\operatorname{AR}(2)$ test should be taken into consideration (Baltagi, 2014). When the coefficients obtained as a result of estimation are examined, it is noticed that in Model 1 NTC variable affects $Q$ variable positively, but it is not significant statistically. The effect of other variables on the dependent variable is statistically significant. One unit increase in SIZE decreases dependent variable by approximately 0,24 . Again one unit increase in LEV decreases dependent variable by approximately 1,41. One unit increase in GROWTH and ROA variables increases dependent variable by 0,0017 and 1,493 respectively. In Model 2, the effect of all variables on dependent variable is statistically significant. The effect of coefficients on dependent variable in Model 2 has similar signs and close values with Model 1. Here the variable which is different is NTC ${ }^{2}$. The coefficient of NTC is positive and statistically significant but the coefficient of $\mathrm{NTC}^{2}$ has negative sign and is statistically significant. This finding shows that there is a non-linear relation between dependent variable Q and NTC. This means that NTC increases dependent variable $\mathrm{Q}$ until a specific point and decreases $\mathrm{Q}$ after this specific point.

\section{Conclusion}

In this study, we investigate the association between working capital management and firm performance for non-financial Turkish firms which are quoted in Borsa İstanbul for the period between 2009-2014.

The working capital investment decisions of the firms are vitally important since firms can proceed their operations without discontinuance, enhance their value and curtail risks as long as working capital level is rigorously managed. Since obtaining liquidity is more difficult and costly, working capital decisions are more important for the firms which operate in emerging countries such as Turkey. Fierce competition worldwide and financial crisis that occurs periodically farther raise the significance of efficient working capital management.

We make a contribution to the working capital literature in the following ways. Primarily, to our knowledge, our paper is the first research in Turkey that investigates the non-linear relationship between NTC and firm performance for the non-financial firms quoted in Borsa İstanbul. Secondly, contemporary data is used in our research, which is further contribution to the literature. Lastly, we utilise Arelano and Bover (1995) and Blundell and Bond (1998) system Panel GMM technique in the analysis to attain credible results.

According to the analysis results, we find a non-linear relation between NTC, which represents working capital management, and firm performance. This inverted U-formed (non-linear) association between NTC and corporate 
performance means that there is an optimal NTC value for which the firm performance is maximised. At this specific point, costs and advantages are poised. So corporate performance goes up as working capital grade increases until this optimal point. But after this specific optimal point is reached, this time the increase in working capital grade starts to decrease the firm performance.

There are some inferences of our analysis that may be useful for both firm executives and academicians, who are conducting research in this field. Firm executives should pay enough attention to their working capital management. Because at the optimal point, firm value is maximised and when the firm falls apart from this specific value firm value suffers. If this working capital administration is not handled properly, this may even end up with bankruptcy. From academic point of view, researchers should also consider possible non-linear relations between the variables selected rather than just analysing linear associations.

In future studies, different proxies other than NTC for working capital management and different variables for the dependent variable other than corporate performance such as gross profit, return on assets, return on equity etc. can be used and it can be tested whether non-linear relation still holds. Some other control variables other than size, leverage, growth opportunities etc. can be added to the research and it can be investigated if analysis outcomes vary. It can be researched whether financing constraints effect the optimal point in terms of working capital management in Turkey to see the influence of internally created funds and reach to external financing (This was analysed by Banos-Caballero et al. (2014) for UK).

\section{References}

Akbulut, R. (2011). İMKB'de imalat sektöründeki işletmelerde işletme sermayesi yönetiminin kârlllık üzerindeki etkisini ölçmeye yönelik bir araştırma. İstanbul Üniversitesi İşletme Fakültesi Dergisi, 40(2), 195-206.

Aktaş, R. (2016). İşletme (çalışma) sermayesi yönetimi [PowerPoint slides]. Retrieved from http://www.fto.org.tr/DB_INT_Image/4/1714/IsletmeSermayesiYonetimi(FTSO).ppt

Almeida, J. R., \& Eid, W. (2014). Access to finance, working capital management and company value: Evidences from Brazilian companies listed on BM \& FBOVESPA. Journal of Business Research, 67, 924-934. http://dx.doi.org/10.1016/j.jbusres.2013.07.012

Anderson, T. W., \& Hsiao, C. (1981). Estimation of dynamic models with error components. Journal of American Statistical Association, 76, 598-606. http://dx.doi.org/10.1080/01621459.1981.10477691

Arellano, M., \& Bond, S. (1991). Some tests of specification for panel data: Monte Carlo evidence and an application to employment equations. Review of Economic Studies, 58, 277-297. http://dx.doi.org/10.2307/2297968

Arellano, M., \& Bover, O. (1995). Another look at the instrumental variable estimation of error-components model. Journal of Econometrics, 68, 29-51. http://dx.doi.org/10.1016/0304-4076(94)01642-D

Aytürk, Y., \& Yanık, S. (2015). Çalışma sermayesi yönetimi Türkiye'deki KOBİ'lerde kârlılığı nasıl etkiler? Muhasebe ve Finansman Dergisi, 10, 157-168.

Baltagi, B. (2014). Econometric Analysis of Panel Data (5th ed.). Wiley, UK: Cornwall

Banos-Caballero, S., Garcia-Teruel, P. J., \& Martinez-Solano, P. (2014). Working capital management, corporate performance and financial constraints. Journal of Business Research, 67, 332-338. http://dx.doi.org/10.1016/j.jbusres.2013.01.016

Blundell, R., \& Bond, S. (1998). Initial conditions and moment restrictions in dynamic panel data models. Journal of Econometrics, 87, 115-143. http://dx.doi.org/10.1016/S0304-4076(98)00009-8

Çakır, H. M. (2013). Nakit döngüsünün firma kârlllı̆̆ına etkisinin sektörel analizi. Journal of Yaşar University, 30(8), 4948-4965

Çakır, H. M., \& Küçükkaplan, İ. (2012). İşletme sermayesi unsurlarının firma değeri ve kârlılığı üzerindeki etkisinin İMKB'de işlem gören üretim firmalarında 2000-2009 dönemi için analizi. Muhasebe ve Finansman Dergisi, 1, 69-86

Cameron, A. C., \& Trivedi, P. (2009). Microeconometrics Using Stata (1st ed.). Texas: Stata Press

Deloof, M. (2003). Does working capital management affect profitability of Belgian firms? Journal of Business Finance \& Accounting, 30(3), 573-587. http://dx.doi.org/10.1111/1468-5957.00008

Demireli, E., Başçı, E. S., \& Karaca, S. S. (2014). İşletme sermayesi ve performans göstergeleri arasındaki ilişkiler: Borsa İstanbul üzerine bir uygulama. Ege Stratejik Araştırmalar Dergisi, 5(1), 79-98.

http://dx.doi.org/10.18354/esam.19583 
Dursun, A., \& Ayrıçay, Y. (2012). Çalışma sermayesi-kârlılık ilişkisinin İMKB örneğinde 1996-2005 dönemi analizi. Atatürk Üniversitesi İktisadi ve İdari Bilimler Dergisi, 26(3-4), 199-214.

Han, C., \& Phillips, P. C. B. (2010). GMM estimation for dynamic panels with fixed effects and strong instruments at unity. Yale University Cowles Foundation Working Paper, 1290, 119-151. http://dx.doi.org/10.1017/s026646660909063x

Karadagli, E. (2013). Profitability effects of cash conversion cycle: Evidence from Turkish companies. Actual Problems of Economics, 141(3), 300-310.

Khadraoui, N. (2012). Financial development and economic growth: Static and dynamic panel data analysis. International Journal of Economics and Finance, 4(5), 94-104. http://dx.doi.org/10.5539/ijef.v4n5p94

Konuk, F., \& Zeren, F. (2014). Is cash conversion cycles optimum in Turkish listed food-beverage firms? Theoretical and Applied Economics, 21(12), 153-164

Lazaridis, I., \& Tryfonidis, D. (2006). The relationship between working capital management and profitability of listed companies in the Athens Stock Exchange. Journal of Financial Management and Analysis, 19(1), 1-12.

Nazir, M. S., \& Afza, T. (2009). Impact of aggressive working capital management policy on firms' profitability. The IUP Journal of Applied Finance, 15(8), 19-30.

Toraman, C., \& Sönmez, A. R. (2015). Çalışma sermayesi ve kârlılık arasındaki ilişki: Perakende ticaret sektörü üzerine bir uygulama. Erzincan Üniversitesi Sosyal Bilimler Enstitüsü Dergisi, 8(1), 15-24.

Vural, G., Sökmen, A. G., \& Çetenak, E. H. (2012). Affects of working capital management on firm's performance: Evidence from Turkey. International Journal of Economics and Financial Issues, 2(4), 488-495.

Yücel, T., \& Kurt, G. (2002). Nakit dönüş süresi, nakit yönetimi ve kârlllık: İMKB şirketleri üzerinde ampirik bir çalışma, IMKB Dergisi, 6(22), 1-15.

Appendix A

\begin{tabular}{llllllllll}
\hline AVOD & ARBUL & BOLUC & CIMSA & EREGL & IZOCM & KOZAL & PRKME & SODA & UNYEC \\
ADANA & ARCLK & BRSAN & DAGI & ERSU & KRDMA & KOZAA & PARSN & SKTAS & VESTL \\
ADEL & ARSAN & BFREN & DMSAS & FMIZP & KRDMB & KRSTL & PENGD & TBORG & VESBE \\
AFYON & ASLAN & BOSSA & DENCM & FROTO & KRDMD & KUTPO & PETKM & TATGD & VKING \\
AKCNS & AYGAZ & BRISA & DERIM & GENTS & KARSN & MAKTK & PETUN & TOASO & YATAS \\
ATEKS & BAGFS & BURCE & DITAS & GEREL & KARTN & MRDIN & PINSU & TRKCM & YUNSA \\
AKSA & BAKAB & BUCIM & DGKLB & GOODY & KATMR & MRSHL & PNSUT & TUKAS & \\
ALCAR & BANVT & COMDO & DURDO & GOLTS & KENT & MNDRS & PIMAS & TMSN & \\
ALKA & BTCIM & CELHA & DYOBY & GUBRF & KERVT & MERKO & PRZMA & TUPRS & \\
ALKIM & BSOKE & CEMAS & EGEEN & HEKTS & KLMSN & TIRE & SAMAT & PRKAB & \\
ALYAG & BRKSN & CEMTS & EGGUB & IHEVA & KNFRT & NUHCM & SARKY & TTRAK & \\
AEFES & BLCYT & CMBTN & EGSER & IHGZT & KONYA & OLMIP & SASA & USAK & \\
ASUZU & BRKO & CMENT & EMKEL & IPEKE & KORDS & OTKAR & SILVR & ULKER & \\
\hline
\end{tabular}

\section{Copyrights}

Copyright for this article is retained by the author(s), with first publication rights granted to the journal.

This is an open-access article distributed under the terms and conditions of the Creative Commons Attribution license (http://creativecommons.org/licenses/by/3.0/). 